\title{
What happened with the grandiose plans? \\ - Strategic plans and network realities in B2B interaction
}

\author{
Christina Öberg ${ }^{1}$ \\ Linköping University \\ Department of Management and Engineering \\ SE-581 83 Linköping \\ Sweden \\ christina.oberg@liu.se
}

\author{
Staffan Brege \\ Linköping University \\ Department of Management and Engineering \\ SE-581 83 Linköping \\ Sweden \\ staffan.brege@liu.se
}

Competitive Paper

25th IMP Conference 2009

Euromed Management, Marseilles, France

Submitted: April 1st, 2009. Revised submission: July 1st, 2009

1 Corresponding author: Christina Öberg, Linköping University, Department of Management and Engineering, SE-581 83 Linköping, Sweden 


\title{
What happened with the grandiose plans? - Strategic plans and network realities in B2B interaction
}

\begin{abstract}
The importance of individual actors in business-to-business relationships has been widely acknowledged. Commonly these are referred to in a process-like manner related to division of work in organisational buying, or they are seen as carriers of values and interactions. In marketing, they are rarely described as representatives of various organisational levels. The purpose of the paper is to discuss business relationships on different organisational levels. We specifically target the strategic perspective of top managers vis-à-vis the operational level of a business relationship. We focus on illustrating the differences between these organisational levels in a dyadic relationship and how differences affect the realisation of intended strategies. We illustrate the strategic and operational levels of a business relationship through a single case study that describes the relationship between BT Industries and Volvo Group. We conclude that top managers had far-reaching plans of change that were not materialised as individuals on operational levels continued as previously. Both parties had quite clear views on the business partner's activities, but due to differences in perspectives, this fundamentally meant quite different understanding of the business relationship. The paper contributes to research on dyadic business relationships through highlighting differences in perspectives of actors on various organisational levels. It also contributes to research on organisations and hierarchies through including a business-relationship aspect. Managerially, the paper helps to understand why strategic plans are not always realised in business-to-business settings.
\end{abstract}

Keywords: Strategy, Organisational levels, Operational, Top Management, Acquisition, Procurement project, Case study 


\section{Introduction}

In a company, decisions and interactions occur at different levels (Franklin, 1975; Gabele, 1981). Strategy literature distinguishes between strategic, tactic and operational decisions. Decisions on a strategic level would affect operational levels of the organisation, and activities on an operational level would sum up and circumstance the strategic level. Nonetheless, it is not certain that company representatives on various levels of an organisation view matters in a consistent way (Longenecker and Gioia, 1992; Aspesi and Vardhan, 1999; Van Der Velde and Jansen, 1999). Similarly in relationships: while it is the activity links, actor bonds and resource ties that together build the relationship with a specific company, individual actors as part of these ties may not necessarily share the same view on the relationship. This is not only a matter of different mindsets among individuals, but also a consequence of that they actually meet different representatives of the other company and thereby potentially also perceive the company's business relationships in different ways.

Webster and Wind (1972) early acknowledged that organisational buying includes a number of actors: users, gatekeepers, purchasers and decision makers. Also on the marketing side, several actors help in selling and marketing a company's service or product. The ARA-model is widely used to depict ties between companies in levels of actors, resources and activities. The components of the model demonstrate that business relationships are multidimensional and the model also shows that the ties could be described on a company, dyadic or network level (Håkansson and Snehota, 1995). Less is however known about such ties on different organisational levels of companies interacting in a dyadic relationship.

A situation where it would become increasingly evident that actors on various organisational levels do not perceive activities and relationships in the same manner is when change is induced on a relationship. In this paper, we describe a top management visà-vis an operational level of relationships related to change processes. The purpose of the paper is to discuss business relationships on different organisational levels. We mainly focus on illustrating the differences between these organisational levels in a dyadic relationship and how this affects the realisation of intended strategies, while how to come to turns with such differences is only touched upon in the concluding managerial implications. The changes introduced to the studied relationship were consequences of acquisitions and a procurement deal. In the paper, aspects of acquisitions and procurement deals are not our specific focus, rather, they are referred to as changes induced on the relationship that makes it possible to study differences at various organisational levels of the relationship.

The paper contributes to research on dyadic business relationships through highlighting differences in perspectives of actors on various organisational levels. It also contributes to research on organisations and hierarchies through including a business-relationship aspect. Managerially, the paper helps to understand why strategic plans are not always realised in business-to-business settings.

The paper is structured the following way: In the next section we relate to previous research on dimensions of business-to-business relationships in marketing and on the hierarchal division of organisations described in organisational theory. Thereafter we outline the research design. The empirical part of the paper is based on a single case study 
researched from the supplier and customer perspective that includes interviewees on the top-management and operational levels of the two companies. Change processes of the involved companies along with a description of the business-to-business relationship are outlined in the section following after the research design. The relationship is analysed and results are reflected upon using additional case studies in the section thereafter. The paper concludes with a concluding discussion including managerial implications and suggestions for further research.

\section{Multidimensional company interfaces}

\section{Individuals in business-to-business marketing}

Researchers have devoted efforts to describe individuals within organisations. Webster and Wind (1972) early described individuals' roles in organisational buying behaviour (see also Webster Jr., 1968). Gatekeepers, users, deciders, buyers and influencers indicate a process-oriented role division between individuals. Hillier (1975) described the role of individuals in companies' buying decisions, and Crow and Lindquist (1985), and Patton III and Puto (1986) focused on individuals as part of companies' buying. The role of salespeople, with specific attention to key account systems, have been scrutinised in literature (Parasuraman, 1975; Johnston and Cooper, 1981; Demirdjian, 1984), thus emphasising individuals of the supplier company. Staples and Coppett (1981) describe how sales staff identifies individual role-keepers of buying firms to target the right audience for sales offers. This consequently creates a link between organisational buying behaviour and the key account/salespeople-literature.

The service marketing literature on organisations (Grönroos, 2000; Zeithaml and Bitner, 2000) emphasises individuals within organisations as important carriers of values and interactions (cf. Vargo and Lusch, 2004). As carriers of interactions, individuals become vital to maintain inter-organisational business relationships. Seabright et al. (1992), Keaveney (1995) and Giller and Matear (2001) have researched how individuals within organisations may affect the probability of relationship dissolution, for example. Relationship marketing (Morgan and Hunt, 1994; Gummesson, 1995; O’Malley, 2003), much influenced by the network approach and service marketing literature, similarly underlines the interpersonal dimension of customer-supplier interactions. The network approach according to the IMP tradition early acknowledged social ties (Hammarkvist et al., 1982; Håkansson, 1982; Hägg and Johanson, 1982). Individual-to-individual relationships may evolve from ongoing company-to-company relationships (Nielson, 1998), and become bridges between relationships (Havila, 1996; Havila and Wilkinson, 2002). However, while business relationships are underpinned by social ties, research focus commonly remains on the company-to-company level of relationships. Recently, interest has been directed to how individuals within organisations perceive the company network (Eriksson and Mattsson, 2002; Ford and Redwood, 2005; Henneberg et al., 2006; Öberg et al., 2007) thus meaning that the unit of analysis may well be individuals rather than companies.

Taken together, individuals as part of business-to-business settings mainly appear as carriers of values and relationships, or as role-keepers. Fundamentally this implies that individuals together contribute to the business relationship, rather than representing various views. A wide-held view of rationality would imply that once individual minds are brought 
together into company settings, they influence each other to make rational choices. Sweeney and Webb (2007) oppose this through pointing at the possible self-interest of individual employees in organisations (cf. agency problems Kesner et al., 1994; Lane et al., 1998). Wagle and Kciminski (1984) describe how individuals in organisations may try to create territorial spaces within organisations for their own good. This all indicates that individuals in organisations do not simply amalgamate into company behaviour. Rather, they may represent different views on matters, and also act according to these views. This is well in line with descriptions of networks based on individual actors' perception (Ford and Redwood, 2005; Henneberg et al., 2006). Individuals as role-keepers, as carriers of relationship values, and perceptions of actors thus acknowledge individuals as important in business-to-business interaction. However, few (if any) studies describe company interfaces on various organisational levels and differences between such levels.

\section{Organisational levels}

In an understanding of multidimensional interfaces of companies, the organisational 'location' of individuals may prove to be important. Expectedly, distance between various organisational levels would create possible differences not only in perception, but also in how individuals interact. With regards to organisational levels, a common way to deal with decision making in organisations is to describe a strategic, tactic and operational level of organisations. Aspesi and Vardhan (1999) and Samuelsson et al. (2006) found gaps between operational and strategic levels of organisations, which meant that strategies were clearly separated from those actually executing them. Lazaric and Raybaut (2005) described difference in cognition within an organisation. Thomas and McDaniel (1990) and Calori et al. (1994) research cognition of top management teams, and Amason and Sapienza (1997), and Van Der Velde and Jansen (1999) describe conflicts of perspectives between managers. While Amason and Sapienza (1997) focus on variations in perspectives between top managers, Van Der Velde and Jansen (1999) research differences in perception between top and middle managers and how this may negatively affect company output. In change processes, Gabele (1981) concludes that different levels of an organisation have different tasks, where a distinction is made between top, middle and low management. Gavetti (2005) describes the co-existence of cognition and organisational hierarchy in capability development of organisations.

Control and how to make various levels of an organisation work to achieve the same goals become central in descriptions including several organisational levels (Franklin, 1975). Longenecker and Gioia (1992) describe how executives make decisions, but the higher up in the organisational hiearchy they are, such decisions will be based on less information on operations and also result in less feedback. Balance scorecards are often mentioned as a control instrument, while other researchers focus more on implementation of systems that make individuals act based on self-interest that simultaneously mean that they act for the company's best of interest. Such ideas underpin many bonus deals of organisations, but also bring research interests into risks for sub-optimal activities of individual actors. Miles and Bennett (2008) discuss top management team and employee motivation following mergers. Dorer and Mahoney (2006) refer to self-actualisation within organisations that may cause severe agency-related problems. There is consequently a quite fundamental difference in belief-systems regarding how to coordinate organisational levels: from direction and control to self-regulating systems of individuals acting based on their selfinterest. 


\section{Organisational levels in business-to-business exchanges}

In literature on various organisational levels, key focus either remains on a specific organisational level, such as top managers, or aim to describe differences in activities and perception between various levels and how to control entire companies. Few studies include parties external to the own organisation. Janowicz-Panjaitan and Krishnan (2009) is one exception to this. In their study they conclude that violation of trust at one organisational level may affect other levels. However, most studies concern intra-company dimensions of organisational levels, while at the same time, the hierarchal orientation of individuals in organisations is rarely found within the marketing literature. There is thus a research gap with regards to differences between organisational levels in business-tobusiness relationships. Through linking research on various organisational levels to the social ties of business-to-business relationships, it would seem apparent that while it is the individual-to-individual relationships of company representatives that together shape the actor bonds of business-to-business relationships, individuals may differ with regards to interests, perception and how they interact with the other party. Figure 1 illustrates actor bonds on various hierarchal levels of organisations involved in a dyadic business-tobusiness relationship.

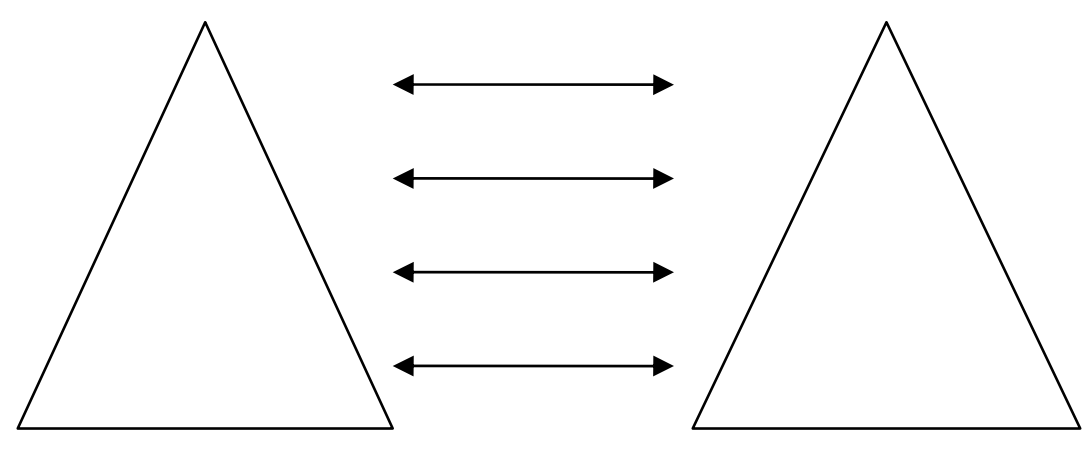

Figure 1: Schematic picture of actor bonds on various organisational levels.

Gabele (1981), Aspesi and Vardhan (1999), and Samuelsson et al. (2006) referred to differences between operational, (tactical) and strategic levels of organisations, where Aspesi and Vardhan (1999), and Samuelsson et al. (2006) refer to a separation between those creating company strategies and those executing them on operational levels of the organisation. In this paper we will highlight ties of relationships on a strategic topmanagement level and on an executing operational level. The illustrating example presented in the paper shows that while individuals of the supplier and customer companies did interact both on a strategic top management level and on an operational level, the relationship was treated fundamentally different on these levels.

\section{Research design}

The paper adopts a case study approach (Yin, 1994; Halinen and Törnroos, 2005; Dul and Hak, 2008). The case study approach allows for the researcher to study companies and events in a context, rather than separated from their context (Johnston et al., 1999; Holmlund, 2004; Halinen and Törnroos, 2005). 
In the paper, we detail on a single dyadic relationship, the relationship between BT Industries and Volvo Group. The specific relationship was chosen as it entailed changes on both the supplier and the customer side of the relationship. Twenty-four interviews were performed with representatives of BT Industries and Volvo Group. In addition, thirteen interviews were conducted with other business partners of BT Industries, eight of which were also business partners of Volvo Group. Interviewees include CEOs, purchase and marketing managers, sales staff and product users, meaning that we grasped both a top management and an operational level of the relationship.

The focus on the dyadic relationship of BT Industries and Volvo Group means that basically, this paper is based on a single case study. The downside of case studies in general, and single case studies in particular, is the degree to which generalisation of findings could be made from the study. Quantitative data allows for the generalisation of findings to a larger extent than do in-depth studies focusing on a limited number of cases. On the other hand, case studies manage to capture details, but also causes and effects in a manner not accomplished in quantitative studies. Transferability (Hirschman, 1986; Guba and Lincoln, 1989) means that while being built on a limited number of cases, or even a single case, findings from studies may well be applicable in wider settings (Easton, 2004). Such transferability inludes that findings from a single case study may create knowledge for other situations and cases, and that findings similar to those derived from a single case study could also be found in other cases (cf. Yin, 1994; Saunders et al., 2007). Interviews with other business partners of BT Industries and Volvo Group, indicatively support findings from our main case study. In an attempt to further verify our findings these were compared with five additional case studies built on a total of fifty-six interviews on business relationships during change processes. Similar to the findings of our focal study, these studies indicate a difference between strategic ideas and operational performance.

The case study was analysed by the authors using a categorisation and recombination of data-technique (Glaser and Strauss, 1967; Strauss and Corbin, 1998). This allowed the authors to be explorative in their data analysis. Such an approach enables the capturing of additional dimensions than those initially under study. In its analysis, individual actors' descriptions of the relationships were analysed so as to conclude how the actors experienced the relationship. Individual actors' stories were compared in order to find possible similarities and differences between perspectives. In the paper, the individual actors' views are treated as organisational representation levels. This is based on analogous descriptions between actors at similar organisational levels. This also means that we treat interviewees' descriptions as being stories on organisational levels, rather than individual persons' perceptions of a given situation.

\section{The BT Industries - Volvo Group relationship}

This section describes the relationship between BT Industries and Volvo Group. It starts off with presenting the individual actors, so as to create an understanding for the companies and the activities they were involved in potentially affecting the business relationship. Thereafter follows a closer description of the relationship between the companies, and whether and how it changed following the activities of the two companies. 


\section{BT Industries}

BT Industries is a Swedish manufacturer of material handling equipment. The company was founded in the 1940s and started off as a sales agent for counterbalanced lifters, but later expanded its scope of business to include warehouse lifter production. Originally, BT Industries operated on its domestic market, but in the 1960s, the company started its international journey. It established sales companies in other European countries, but also grew through acquisitions. In the 1980s, BT Industries became a transatlantic company through its acquisitions of Lift-Rite in Canada and Prime Mover in the US. Still, the European operations dominated the company until the latter part of the 1990s. In fierce competition with two major European actors, Linde and Jungheinrich, BT Industries struggled financially and also had difficulties to build additional relationships. As a means to differentiate its offering, the company came to adopt a business model including service provision to customers. Partnerships increasingly became part of the company's geographical expansion, mainly as a result of profitability problems and of difficulties to attain positions on new markets. This included the joint venture between BT Industries and Cesab on the Italian market. While still cringing at the position as number three on the European market, the latter part of the 1990s meant that BT Industries had regained a financial strength that allowed for the company to introduce an expansion strategy. The company outlined some different strategic options, investigated alternatives for acquisitions and considered whether the company should expand geographically or into related product areas. BT Industries had had problems to attain a strong position in the US, and during the strategic work, the US warehouse manufacturer Raymond was identified as an interesting target for acquisition. BT Industries' acquisition of Raymond became a means for BT Industries to reached a desired position on the US market. Acquisition motives entailed economies of scale through integrated purchasing, product development and cross-supply. Aims were to make lifters together, and also to use production facilities of the companies for a more flexible production. On the marketing side, this would mean introducing common lifters, but furthermore: the acquisition was strongly oriented to connecting customers of Raymond with BT Industries, and customers of BT Industries with Raymond. Following the acquisition, nothing much happened with regards to coordination of operations between BT Industries and Raymond. The companies largely continued as previously and few global deals were signed. Customers did not seem to see the advantage in the global offering of BT Industries/Raymond.

In a next strategic step, BT Industries acquired the previous cooperation partner Cesab. This acquisition aimed to provide BT Industries with counterbalanced lifters. The acquisition also was a means for BT Industries to secure its Italian operations (Cesab's country of origin and the market for the joint venture between BT Industries and Cesab). Outside the Italian market, motives were strongly oriented towards BT Industries providing a complete offering of lifters. Following from the acquisition, such offerings were only partially embraced by customers, and further: brands, sales channels and contact persons were kept as before the acquisition.

In the year 2000, BT Industries found itself acquired by Toyota Industry Corporation, a major player in the lifter market. Toyota's ambition with the acquisition was to create a world-wide dominance in the material handling equipment segment. Motives stressed synergies in marketing, distribution and service. Research and development were expected to become more efficient as the acquisition would allow for additional resources to be placed in the area (Wäingelin, 2000). On an overall level, a combined company acting as a 
world leader on material handling equipment was strongly emphasised. However, following the acquisition, the companies remained independent units to large extents.

Organisation of operations remained decentralised in many aspects in BT Industries and in the Toyota group. BT Industries had traditionally worked with local sales representatives and local support organisations that carried much of the daily interaction with customers. Attempts to centralise operations followed the acquisitions, but were to large extents not materialised. A new organisational layer was introduced, and integration attempts between original and acquired companies were attempted. However, on local levels, and among the acquired parties, there were low interests to follow new ways of operating.

\section{Volvo Group}

Volvo Group's history runs back to the 1920s. The company started off as a manufacturer of cars, located in the south-west of Sweden. The first car was presented in 1927, but already the year thereafter, Volvo Group manufactured its first truck. Exports of trucks soon followed, where Europe was the main domain for sales outside Sweden. Acquisitions broadened the product portfolio to entail marine engines (through the acquisition of Pentaverken in 1935), but the company also diversified its business into related fields based on its own capacity. Buses and aircraft engines were introduced during the first half of the twentieth century.

The company has survived financial crises, and undergone several changes with regards to diversification and streamlining of operations. At times, the company was an industry conglomerate with a far-reaching portfolio from vehicles to food. During the pace of the years, Volvo Group expanded geographically to become a world-wide actor. The turn of the millennium meant major changes in Volvo's business structure. In 1999, Volvo Car was divested. Ford Motor Company became the owner of the business that had previously been regarded as the heart of Volvo Group's operations (Giertta, 1999; Lövgren, 1999). Following from the divesture of Volvo Car, Volvo Group's business incorporated Volvo Trucks, Volvo Buses, Volvo Construction Equipment, Volvo Penta, Volvo Aero and Volvo Financial Services (Sweden). A consolidation wave swept the industry, and Volvo Group saw the risk of being acquired, which meant that the company intensively searched for acquisition targets to possibly avoid such a development. Volvo aimed to acquire the Swedish truck manufacturer Scania, but was turned down by the competition authority. In 2001, Volvo Group acquired Renault Trucks and its subsidiary Mack, both of which operated in the truck segment with geographical residences in France and the US, respectively. Renault had a strong position in Europe, South America and North Africa, while Mack mainly acted on the US market. Volvo Group wanted to strengthen its position in the US (Wäingelin, 1999) and Mack would enable such an expansion. Volvo Group had a clearly stated business mission; to be valued as the world's leading supplier of commercial transport solutions. Considerable integration efforts followed the acquisition. Common components would characterise the trucks, while brands would be kept separate, where differentiation would mainly appear in the cabin design. Purchasing, development, design and production would be integrated (Andersson, 2000). On the marketing side, the company aimed for global offerings and also to broaden the portfolio to include services and the like. Following the acquisition, Volvo Global Trucks was formed. Fast integration was prompted by the company. Volvo Group had however problems to reach profitability in its US operations, including foremost Volvo Group's existing operations, but also Mack. Staff was laid off, and as it turned out, few global deals were reached. 
One area that came to attract attention following the acquisitions was procurement of material handling equipment. Such procurement had largely been a local activity comprised at 1.600 different locations. In order to lower costs and increase control, a procurement project was started in 2001 aiming at creating global procurement contracts. Prior to the procurement project, Volvo Group bought 600 lifters per year, and owned a total of 4.688 at the beginning of the project. With local procurement, a variety of lifter suppliers were used; in total 19 different suppliers, and price and other conditions were negotiated locally (Volvo, 2002). The global procurement lifter project aimed at lowering cost of ownership for material handling equipment with thirty percent and was driven by a project group consisting of representatives from Volvo, Renault and Mack, and the different production plants in the group. The project included the material handling equipment, while service agreements, often part of a material handling deals, were to be purchased locally. 800 offerings were analysed. Price, the geographical presence and earlier experience (feedback from the lifter users) were the three determinants, though with a main focus on "hard values". The project resulted in three preferred suppliers: Toyota/BT, Still (owned by Linde) and Hyster (owned by Nacco). Price frame deals were signed on a three year basis with each of these suppliers. Once the deals were signed, the commitment towards the chosen suppliers was shown through measures being taken towards local units buying from other parties.

Volvo Group thus aimed to centralise its activities. Operational levels of the organisation had previously to large extents made their own decisions regarding procurement. Following the acquisitions, this continued to large extents although centralisation was imposed on the organisation. Within the frames of rules set on strategic levels, operational levels continued to act as previously.

\title{
The BT Industries - Volvo Group relationship
}

BT Industries and Volvo (Group) both belong to traditional Swedish industry sectors and share history. For BT Industries, car manufacturers had been a prioritised business area, and the company had a specific sales organisation in Sweden directed to car manufacturers. Recent years prior to the intensive acquisition activities of BT Industries, managers of BT Industries had experienced that customers increasingly came to focus on price, and also that they tended to centralise their purchasing. Volvo was no exception to the rule, where the procurement project clearly indicated an attention to centralised deals.

\begin{abstract}
So we can see that the customers have tended to become more and more unfaithful, if I may put it that way. Relationships are not as important. So once you discover that a customer that has been warm and kind for years has reorganised, something else happens. And a person appears who is between twenty-five and thirty and good at spreadsheets - then we know something has happened. Now they have decided that price is what matters.
\end{abstract}

Christer Högberg, President, BT Europe

Other trends included globalisation, preferred supplier deals, and attempts to break up combined deals (product and services) into parts, in order to decrease dependence. Volvo (Group)'s development fits well into that description. The acquisitions of Renault Truck and Mack meant an increased global presence, and the procurement project aimed to centralise purchasing and also to put pressure for cost reductions. In its procurement deal, Volvo Group had emphasised the separation of services from products. With regards to 
globalisation and preferred supplier deals, BT Industries' acquisitions aimed to meet such trends.

Prior to Volvo Group's procurement project, the relationship between BT Industries and Volvo Group was largely dependent on local contacts; the district sellers and service engineers of BT Industries and the users and local purchase managers of Volvo Group.

Back then you could choose whichever lifter supplier you wanted. We had BT already then, we have had BT since this factory was built in 1977.

Bo Sköldebring, Purchase, Volvo Bus Corporation

BT Industries provided trucks and often also services to local representatives of Volvo Group. Service personnel created strong ties on local levels, as it often meant that these were present at Volvo's sites on a daily basis. Service contracts were negotiated on a yearly or semi-yearly basis, but the presence of the BT Industries' service personnel created a continuity that often meant that contracts were continuously renewed without Volvo searching for other alternatives. As for the trucks, these were commonly owned by Volvo.

The acquisitions (BT Industries' and Volvo Group's) and transitions of organisational structures that followed, would be expected to lead to quite many changes in the companies' business relationships. BT Industries aimed to become a preferred supplier through its provision of warehouse and counterbalanced lifters. The global organisational structure that followed Toyota's acquisition of BT Industries would fit customers' increased global foci. For Volvo Group, a globalisation trend was obvious among customers, which Volvo Group followed. Price focus intensified and centralisation of procurement deals on a global basis, was on the top of the agenda. Figure 2 outlines Volvo Group's business relationships with BT Industries and other lifter suppliers following the procurement project.

Volvo Group wanted to strengthen its negotiation power vis-à-vis truck suppliers and therefore separated truck deals from service agreements. The service agreements were not included in the procurement deal, but were to be negotiated locally. 


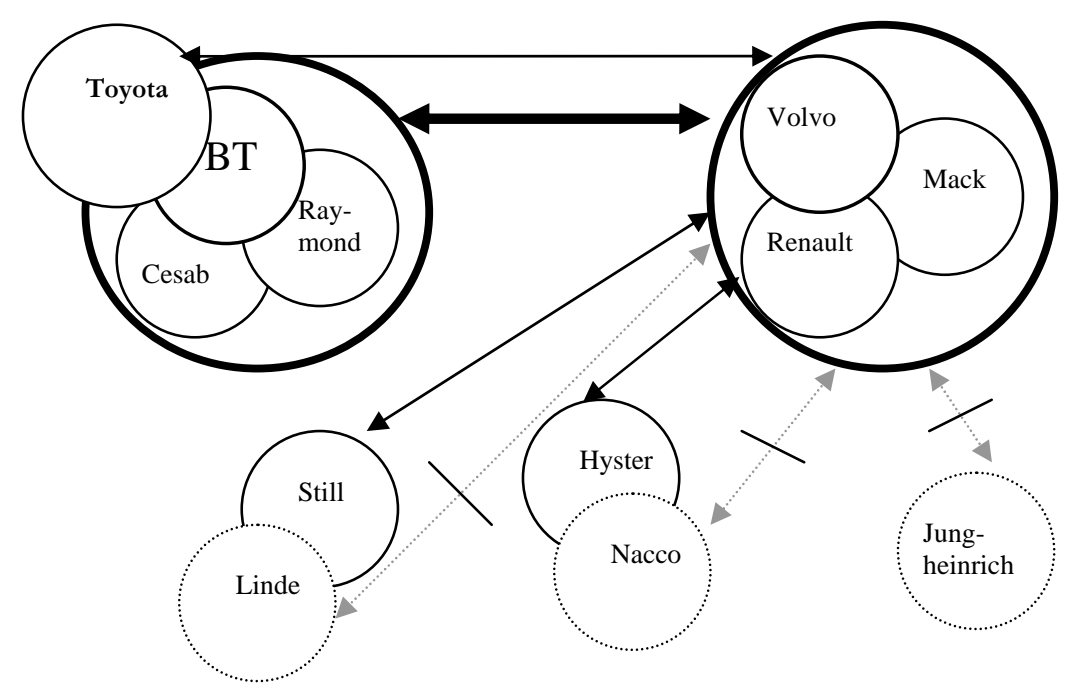

Figure 2: Volvo Group's relationships with BT Industries and other lifter suppliers following the procurement project.

However, while imposing a redirected focus on the organisations, in several aspects, no changes appeared on the local levels of the business relationship. Although the procurement project aimed at changing the method of purchasing, local examples indicate a status quo in relationships. Let us take a further look at two examples on the operational levels of the organisations: the US operations of the companies, and the Swedish counterparts.

\section{US operations}

Volvo Group and BT Industries both had problems to control their US operations. While BT Industries included Raymond in possible global deals, the company did not manage to actually close any deals of deliveries in the US as part of these deals. Raymond did not participate in planned development projects and manifested its independence on operational levels following BT Industries’ acquisition.

Raymond does not feel as though they are part of BT... I do not think that they have sold any lifters at all; even Toyota is more active in the US.

Jan Söderlund, Purchase Manager/World-wide Manager Procurement Project, Volvo NAP

Volvo Group indicates a similar story: Mack was not active in global undertakings, and also following the global procurement project, Mack tried to maintain its relationships with previous lifter suppliers. In the case of the companies' US operations, it thus seems to not merely be a question of whether strategies were properly implemented on operational levels. It also seems to be a case of companies trying to maintain their previous independence.

\section{Swedish market}

While reactions to new owners may explain differences between strategies and operational levels in the US, it does not explain why operations in Sweden continued as before. 
Operational levels of Volvo Group continued to interact with operational levels of BT Industries. For instance, BT Industries had been the main truck supplier for Volvo Bussar in Borås since 1977, and BT Svenska remained the only supplier following the acquisitions and procurement project. Service was also purchased from the Swedish sales organisation BT Svenska, and a BT Industries’ service engineer remained placed at the Borås plant. These parties did not see any reason to reconsider service agreements or supplier deals as long as they did not violate the preferred supplier deals of Volvo Group. Also while underpinned by these deals, much of the purchasing process remained as before, with no or limited involvement of new individuals:

\footnotetext{
The engineer in the warehouse here makes the specification together with the truck users. And then we go and look at the truck at the supplier's spot, tries it. The truck is specified and we attain an offer from BT Industries, which the engineer and users go through to make sure that everything is as it is supposed to be.
}

Bo Sköldebring, Purchase, Volvo Bus Corporation

In sum, top managers of both BT Industries and Volvo Group had expected more global deals than were actually realised. The BT Industries' management had anticipated to sell both counterbalanced and warehouse lifters following the acquisitions, and succeeded in doing so to various extents, yet not to expected amounts. Volvo Group meant to reduce its overall number of lifters, but did not succeed in the US. The procurement deal that would lead to centralised purchasing often meant that operational levels continued as before, while the deal aimed to break apart existing structures to decrease dependence and lower price.

\section{Analysis}

The relationship between BT Industries and Volvo Group describes a business relationship involving several intended changes on strategic levels. BT Industries became a full range supplier acting on a global level. Volvo Group similarly increased its global presence, centralised purchasing and negotiated preferred supplier deals. Still, local representatives on operational levels of the companies did not perceive any major changes in the relationship. Apart from the exclusion of companies following Volvo Group's procurement project, none of the changes introduced by either party meant a change that the other party needed to follow. And, the procurement project affected excluded companies, while those that attained the preferred supplier contracts could continue as previously.

The strategic activities were based on other parties' activities, meaning that they were responding rather than aimed to redraw network settings. BT Industries' globalisation was a means to meet globalisation among customers (such as Volvo Group). The full range supply aimed to encounter preferred supplier deals. This indicates that the intentions on strategic levels were results of plans that were founded in the companies' networks (cf. Håkansson and Ford, 2002; Ford and Håkansson, 2006). However, they did not manage to direct activities on local levels, or local levels of relationships coped with the changes in manners that left them unaffected. That operational levels of relationships continued as before virtually meant that activities planned on strategic levels could not be fully accomplished. This is similar to ideas on organisational levels presented by Aspesi and Vardhan (1999) and Longenecker and Gioia (1992). 
The case indicates a clear difference in expectations on interaction, and activities, between top management teams and representatives on operational levels of organisations. Of interest is that the individuals on the strategic, top-management level acted upon their preunderstanding of the network, while operational staff acted on theirs. This means that it is not simply a matter of strategies being separated from realities (Longenecker and Gioia, 1992; Aspesi and Vardhan, 1999), but a matter of various company representatives seeing and interpreting the surrounding network in different manners. Why is this so?

One explanation for operational and strategic levels of organisations not working together is that of creating independence within organisations. Wagle and Kciminski (1984) refer to how parties may try to create territories within organisations. This would mean that the local levels tried to maintain their positions vis-à-vis business partners as a means to remain independent and decide over sales and purchasing themselves.

Other explanations may find their cause in that the acquisitions not created strong enough links to the new owners. Rather, local operations found stronger relationships with existing business relationships than with the new owners. Therefore, aspects of loyalty would be directed to business partners at the expense of creating relationships with, and following directions of, the new owners. Uncertainty related to change, may also mean that individuals as part of business relationships try to maintain existing business partners (cf. Spekman and Ford, 1977).

However, and what mainly seems to be the case is that company representatives on various organisational levels acted on the relationship they saw. Top managers at strategic levels of the organisation were concerned with how business partners acted in terms of acquisition strategies, etc. Top managers consequently acted on these changes and planned for own activities to meet these changes. Implementation of such strategies however mainly occurred at operational levels of the companies. This means that the top managers did not have the first hand information on how business partners handled the new situations; the non-integration that followed, and so on. The operational level of the relationships did on the other hand not primarily focus on the acquisitions or centralised purchasing. Instead, it saw its core business to act and interact with business partners on operational levels. Consequently, the operational levels continued to act as previously, and were not largely interrupted by the activities on strategic levels. In some instances, local levels drove the development that meant that acquirers and acquired companies were not integrated, for instance, but what also happened was that the operational levels were never introduced to intended integration ideas.

\section{Concluding discussion}

This paper brings together perspectives of different organisational levels, and actor bonds in business-to-business relationships. Studies including various organisational levels common take an intra-company perspective. And, research on individuals in business-tobusiness marketing settings has either referred to individuals as carriers of values, interaction and as parts in buying processes. Built on ideas of that actor bonds are important in business-to-business settings (Håkansson, 1982; Håkansson and Ford, 2002; Ford and Håkansson, 2006) and that individuals within an organisation may differ in perception built on their organisational level (Van Der Velde and Jansen, 1999), we discuss business relationships on different organisational levels. We specifically target the strategic perspective of top managers vis-à-vis the operational level of a business 
relationship in a dyadic relationship. The relationship between BT Industries and Volvo Group illustrates that company representatives considered but also acted on the relationship in different manners. On the strategic level, attention was directed to globalisation, preferred supplier deals, increased price focus and centralised purchasing, while the operational level of the relationships continued as previously. The strategic level aimed at both making the relationship closer and more distanced and also aimed to increase power vis-à-vis dependence between the actors (cf. relationship atmosphere, Anderson et al., 1994; Blankenburg Holm, 1996; Gadde, 2004). Centralised purchasing would fundamentally increase the possibility to put pressure on suppliers and also to break apart old relationships, while responding to internationalisation through creating a global offering aimed to tighten the relationship between supplier and customer. On operational levels however, relationships remained as previously.

In the case of BT Industries and Volvo Group, activities on the top-management level were responses to other activities on that level. This means that differences between strategic and operational levels of the organisations were fundamentally results of different understanding of the business relationship. The top management level was primarily concerned with the strategies outlined by the other party, while the operational level of organisations saw the business relationship in the light of their interaction with operational levels of the other party. This in turn made it difficult to actually achieve those goals outlined on strategic levels.

The BT Industries/Volvo Group relationship illustrates a situation where the companies on strategic levels followed each others activities. In the verifying studies we have made, we however find circumstances of where one party acted without this being built on understandings of the other companies' activities. The company tried to redraw the network setting through creating ties and demands that did not match activities of others. Also in that case there was a clear discrepancy between strategic and operational levels of organisations. As in the BT Industries/Volvo Group relationship, continuity and ties on operational levels meant that strategic ideas were not fully put into practice.

Taken together, differences between strategic and operational levels make it difficult to achieve intended company goals. Fundamentally, the operational level preserves existing relationship characteristics, while strategic levels may aim to change these. In none of our verifying studies did we found any evidence for that operational levels would be those that drove change processes in relationships. Rather, actor bonds on operational levels were those that maintained relationship structures in times of uncertainty on a business-tobusiness relationship level. Through analysing actor bonds on various organisational levels of relationships, it becomes evident that these need to work together if changes should really be realised.

\section{Managerial implications}

In the title of this paper we ask "What happened with the grandiose plans?”. This rhetoric question aim to underline the difficulty of achieving strategic goals outlined on top management levels of organisations. To realise strategies, these need to be implemented and understood at all levels of an organisation. In service marketing, emphasis is placed on internal marketing, which means that it is important not only to market the company to external parties, but also to do so within the organisation. This may work as systems to make strategic and operational levels of organisations connect. Further, it would be 
important to understand operational levels of relationships before planning strategies that may not meet approval there.

When companies centralise their purchasing, they fundamentally increase the distance between buying strategies and sales staff/user-interactions on operational levels of organisations. The sheer awareness of differences in understanding of business relationship is important to take into account in activities both on a strategic and operational level of the organisations. For managers it thus becomes important not only to understand the own situation from management perspectives, but also operational levels, and how individuals on strategic and operational levels of business partners act. The inclusion of staff from operational levels in strategy discussions would be one way to improve such understanding, along with the awareness that strategies will not be realised unless managers share their pre-understanding with operational levels of organisations.

\section{Further research}

For further research, it would be interesting to research how companies can achieve a more coherent view on business relationships. How could perception on strategic levels of organisations be communicated to operational levels, and reverse? In this paper we focused on a single dyadic relationship. For further research it would be interesting to study discrepancies on various organisational levels in network settings. Such studies could include studying layers of actor bonds and how well various layers correspond to each other, and what effects differences between them bring about.

\section{References}

Amason, A.C. and Sapienza, H.J. (1997), "The effects of top management team size and interaction norms on cognitive and affective conflict", Journal of Management, Vol. 23 No. 4, pp. 495-516.

Anderson, J.C., Håkansson, H. and Johanson, J. (1994), "Dyadic business relationships within a business network context", Journal of Marketing, Vol. 58 No., pp. 1-15.

Andersson, N. (2000), Renault inte sista köpet för volvo, NyTeknik.

Aspesi, C. and Vardhan, D. (1999), "Brilliant strategy, but can you execute?" McKinsey Quartely, No. 1, pp. 88-99.

Blankenburg Holm, D. (1996), Business network connections and international business relationships, Företagsekonomiska institutionen, Uppsala University.

Calori, R., Johnson, G. and Sarnin, P. (1994), "Ceos' cognitive maps and the scope of the organization", Strategic Management Journal, Vol. 15 No. 6, pp. 437-457.

Crow, L.E. and Lindquist, J.D. (1985), "Impact of organizational and buyer characteristics on the buying center", Industrial Marketing Management, Vol. 14 No. 1, pp. 49-58.

Demirdjian, Z.S. (1984), "A multidimensional approach to motivating salespeople", Industrial Marketing Management, Vol. 13 No. 1, pp. 25-32. 
Dorer, H.L. and Mahoney, J.M. (2006), "Self-actualisation in the corporate hierarchy", North American Journal of Psychology, Vol. 8 No. 2, pp. 397-409.

Dul, J. and Hak, T. (2008), Case study research methodology in business research, Butterworth-Heinemann/Elsevier, Oxford.

Easton, G. (2004), "One case study in enough", No.

Eriksson, K. and Mattsson, J. (2002), "Managers' perception of relationship management in heterogeneous markets", Industrial Marketing Management, Vol. 31 No. 6, pp. 535-543.

Ford, D. and Håkansson, H. (2006), "The idea of interaction", The IMP Journal, Vol. 1 No. 1, pp. 4-27.

Ford, D. and Redwood, M. (2005), "Making sense of network dynamics through network pictures: A longitudinal case study", Industrial Marketing Management, Vol. 34 No., pp. 648-657.

Franklin, J.L. (1975), "Down the organisation: Influence processes across levels of hierarchy", Administrative Science Quarterly, Vol. 20 No. 2, pp. 153-164.

Gabele, E. (1981), "The management of change", International Studies of Management and Organization, Vol. 11 No. 1, pp. 56-74.

Gadde, L.-E. (2004), "Activity coordination and resource combining in distribution networks - implications for relationship involvement and the relationship atmosphere." Journal of Management Studies, Vol. 20 No. 1/2, pp. 157-184.

Gavetti, G. (2005), "Cognition and hierarchy: Rethinking the microfoundations of capabilities' development", Organization Science, Vol. 16 No. 6, pp. 599-617.

Giertta, C. (1999), "Det här är det enda vi kan göra", Dagens Nyheter - Ekonomi, Stockholm.

Giller, C. and Matear, S. (2001), "The termination of inter-firm relationships", The Journal of Business and Industrial Marketing, Vol. 16 No. 2, pp. 94-112.

Glaser, B.G. and Strauss, A.L. (1967), The discovery of grounded theory - strategies for qualitative research, Weidenfeld \& Nicolson, London.

Grönroos, C. (2000), Service management and marketing: A customer relationship management approach, John Wiley \& Sons.

Guba, E.G. and Lincoln, Y.S. (1989), Fourth generation evaluation, Sage, Newbury Park.

Gummesson, E. (1995), Relationsmarknadsföring: Från 4p till 30r, Liber-Hermods, Malmö. 
Halinen, A. and Törnroos, J.-Å. (2005), "Using case methods in the study of contemporary business networks", Journal of Business Research, Vol. 58 No., pp. 1287-1297.

Hammarkvist, K.-O., Håkansson, H. and Mattsson, L.-G. (1982), Marknadsföring för konkurrenskraft, Liber, Malmö.

Havila, V. (1996), "When does an international business relationship become nonexistent?" 25th EMAC Conference, Budapest University of Economic Sciences.

Havila, V. and Wilkinson, I. (2002), "The principle of the conservation of relationship energy: Or many kinds of new beginnings", Industrial Marketing Management, Vol. 31 No., pp. 191-203.

Henneberg, S.C.M., Mouzas, S. and Naudé, P. (2006), "Network pictures - a concept of managers' cognitive maps in networks", European Journal of Marketing, Vol. 40 No. 3/4, pp. 408-429.

Hillier, T.J. (1975), "Decision-making in the corporate industrial buying process", Industrial Marketing Management, Vol. 4 No. 2/3, pp. 99-106.

Hirschman, E.C. (1986), "Humanistic inquiry in marketing research: Philosophy, method and criteria", Journal of Marketing Research, Vol. 23 No., pp. 237-249.

Holmlund, M. (2004), "Analyzing business relationships and distinguishing different interaction levels", Industrial Marketing Management, Vol. 33 No., pp. 279-287.

Håkansson, H., Ed. (1982), International marketing and purchasing of industrial goods an interaction approach, John Wiley \& Sons Ltd, London.

Håkansson, H. and Ford, D. (2002), "How should companies interact in business networks?" Journal of Business Research, Vol. 55 No., pp. 133-139.

Håkansson, H. and Snehota, I. (1995), Developing relationships in business networks, Routledge, London.

Hägg, I. and Johanson, J., Eds. (1982), Företag i nätverk - ny syn på konkurrenskraft, Studieförbundet näringsliv och samhälle, Stockholm.

Janowicz-Panjaitan, M. and Krishnan, R. (2009), "Measures for dealing with competence and integrity violations of interorganizational trust at the corporate and operating levels of organizational hiearchy", Journal of Management Studies, Vol. 46 No. 2, pp. 245-268.

Johnston, W.J. and Cooper, M. (1981), "Analyzing the industrial salesforce selection process", Industrial Marketing Management, Vol. 10 No. 2, pp. 139-147.

Johnston, W.J., Leach, M.P. and Liu, A.H. (1999), "Theory testing using case studies in business-to-business research", Industrial Marketing Management, Vol. 28 No., pp. 201213. 
Keaveney, S.M. (1995), "Customer switching behavior in service industries: An exploratory study", Journal of Marketing, Vol. 59 No., pp. 71-82.

Kesner, I.F., Shapiro, D.L. and Sharma, A. (1994), "Brokering mergers: An agency theory perspective on the role of representatives", Academy of Management Journal, Vol. 37 No. 3, pp. 703-721.

Lane, P.J., Cannella Jr., A.A. and Lubatkin, M. (1998), "Agency problems as antecedents to unrelated mergers and diversification: Amihud and lev reconsidered", Strategic Management Journal, Vol. 19 No. 6, pp. 555-578.

Lazaric, N. and Raybaut, A. (2005), "Knowledge, hierarchy and the selection of routines: An interpretative model with group interactions", Journal of Evolutionary Economics, Vol. 15 No. 4, pp. 393-421.

Longenecker, C.O. and Gioia, D.A. (1992), "The executive appraisal paradox", Academy of Management Executive, Vol. 6 No. 2, pp. 18-28.

Lövgren, S. (1999), Siffrorna styr - inte känslorna, Göteborgs-Posten, Göteborg.

Miles, S.A. and Bennett, N. (2008), "6 steps to (re)building a top management team", MIT Sloan Management Review, Vol. 50 No. 1, pp. 60-64.

Morgan, R.M. and Hunt, S.D. (1994), "The commitment-trust theory of relationship marketing", Journal of Marketing, Vol. 58 No., pp. 20-38.

Nielson, C.C. (1998), "An empirical examination of the role of 'closeness' in industrial buyer-seller relationships." European Journal of Marketing, Vol. 32 No. 5/6, pp. 396-426.

O’Malley, L. (2003), "Relationship marketing", S. Hart, Marketing changes, pp.

Öberg, C., Henneberg, S.C. and Mouzas, S. (2007), "Changing network pictures: The evidence from mergers and acquisitions", Industrial Marketing Managemenent, Vol. 36 No. 7, pp. 926-940.

Parasuraman, A. (1975), "Assigning salesmen to sales territories: Some practical guidelines", Industrial Marketing Management, Vol. 4 No. 6, pp. 335-341.

Patton III, W.E. and Puto, C.P. (1986), "Which buying decisions are made by individuals and not by groups?" Industrial Marketing Management, Vol. 15 No. 2, pp. 129-138.

Samuelsson, P., Ekendahl, P. and Ekevõrn, P. (2006), "Strategic or operationasl perspectives on performance: What is prioritized in a large construction company?" Measuring Business Excellence, Vol. 10 No. 1, pp. 36-47.

Saunders, M., Lewis, P. and Thornhill, A. (2007), Research methods for business students, Prentice Hall, Essex. 
Seabright, M.A., Levinthal, D.A. and Fichman, M. (1992), "Role of individual attachments in the dissolution of interorganizational relationships", Academy of Management Journal, Vol. 35 No. 1, pp. 122-.

Spekman, R.E. and Ford, G.T. (1977), "Perceptions of uncertainty within a buying group", Industrial Marketing Management, Vol. 6 No. 6, pp. 395-403.

Staples, W.A. and Coppett, J.I. (1981), "Sales presentations at three company levels", Industrial Marketing Management, Vol. 10 No. 2, pp. 125-128.

Strauss, A. and Corbin, J. (1998), Basics of qualitative research - techniques and procedures for developing grounded theory, Sage, Thousand Oaks.

Sweeney, J.C. and Webb, D.A. (2007), "How functional, psychological, and social relationship benefits influence individual and firm commitment to the relationship", Journal of Business \& Industrial Marketing, Vol. 22 No. 7, pp. 474-488.

Thomas, J.A. and McDaniel, J., Reuben R. (1990), "Interpreting strategic issues: Effects of strategy and the information-processing structure of top management teams", Academy of Management Journal, Vol. 33 No. 2, pp. 286-306.

Wagle, J.S. and Kciminski, P.F. (1984), "Applying territoriality to steps in the buyer/seller process", Industrial Marketing Management, Vol. 13 No. 1, pp. 1-10.

Van Der Velde, M.E.G. and Jansen, P.G.W. (1999), "Managerial activities among top and middle managers: Self versus other perceptions", Journal of Applied Management Studies, Vol. 8 No. 2, pp. 161-174.

Vargo, S.L. and Lusch, R.F. (2004), "Evolving to a new dominant logic for marketing", Journal of Marketing, Vol. 68 No., pp. 1-17.

Webster, F.E.J. and Wind, Y. (1972), Organizational buying behavior, Prentice-Hall Inc., Engelwood Cliffs, New Jersey.

Webster Jr., F.E. (1968), "On the applicability of communication theory to industrial markets", Journal of Marketing Research, Vol. 5 No. 4, pp. 426-428.

Volvo (2002), Global volvo forklift project.

Wäingelin, J. (1999), Heta rykten om volvoaffärer, Dagens Industri, Stockholm.

Wäingelin, J. (2000), Börs \& finans: Toyota förvärvar bt, Dagens Industri.

Yin, R.K. (1994), Case study research - design and methods, Sage Publications, Inc., Thousand Oaks.

Zeithaml, V. and Bitner, M. (2000), Service marketing: Integrating customer focus across the firm, Irwin, McGraw-Hill. 
